\title{
Heavy Metal Ions Adsorption from Wastewater Using Activated Carbon from Orange Peel
}

\author{
JUAN CARLOS MORENO-PIRAJÁN ${ }^{1 *}$, and LILIANA GIRALDO ${ }^{2}$ \\ ${ }^{1}$ Facultad de Ciencias, Departamento de Química \\ Grupo de Investigación en Sólidos Porosos y Calorimetría \\ Universidad de los Andes, Colombia \\ ${ }^{2}$ Facultad de Ciencias \\ Departamento de Química, Universidad Nacional de Colombia \\ jumoreno@uniandes.edu.co
}

Received 13 May 2011; Revised 14 May 2011; Accepted 5 June 2011

\begin{abstract}
Activated carbon obtained from orange peel (ACOP) was synthesized and used for the removal of heavy metal ions $(\mathrm{Cr}, \mathrm{Cd}$, and $\mathrm{Co})$ from aqueous solutions. Two different adsorption models were used for analyzing data. Adsorption capacities were determined: copper ions exhibit the greatest adsorption on activated carbon orange peel because of its size and $\mathrm{pH}$ conditions. Adsorption capacity varies as a function of $\mathrm{pH}$. Adsorption isotherms from aqueous solution of heavy metals on ACOP were determined. Adsorption isotherms are consistent with Langmuir's adsorption model. Adsorbent quantity and immersion enthalpy were studied.
\end{abstract}

Keywords: Orange peel activated carbon, Immersion enthalpy, Adsorption, Heavy metals.

\section{Introduction}

At present, adsorption is widely accepted in environmental treatment applications throughout the world. Liquid-solid adsorption systems are based on the ability of certain solids to preferentially concentrate specific substances from solutions onto their surfaces. This principle can be used for the removal of pollutants, such as metal ions and organics, from wastewaters ${ }^{1-4}$. Extensive research has been carried out during the last ten years to find low-cost, high capacity adsorbents for the removal of metal ions. A wide range of adsorbents have been developed and tested, including several activated carbons ${ }^{5-8,9-23}$. There are two processes for preparation of activated carbon: chemical activation and physical activation. Chemical activation is known as a single step method of preparation of activated carbon in the presence of chemical agents. Physical activation involves carbonization of a carbonaceous materials followed by activation of the resulting char in the presence of activating agents such as $\mathrm{CO}_{2}$ or steam. The chemical activation usually takes place at a temperature lower than that used in physical activation, therefore it can improve the pore development in the carbon structure because the effect of chemicals. The carbon yields of chemical activation are 
higher than physical one ${ }^{8,23-42}$. Cassava is one of the most important foods in Colombia, an agricultural country. Cassava is one of the primary foods in our country and usually used for traditional food, cake, etc. The cassava production in Colombia is very huge and only small amounts are utilized by traditional food industries, and the rest are used as the raw material for cassava starch industries. Cassava starch making operation produces a large amount of solid wastes (cassava peel), and direct discharge of this solid wastes will cause the environmental problems. Here we report on the porous texture characteristics of ACs prepared by $\mathrm{KOH}$ activation of orange peel, i.e. the shells covering orange. These constitute a by-product from orange processing following harvest with few practical applications and whose uncontrolled spill (e.g. in rivers) causes some environmental concern. In fact, applications of orange are limited to use as fuel or as feedstock to obtain food for animal. We will show that carbon adsorbents with high surface areas and pore volumes can be obtained from this material, and that development of the porous structure can be modulated by changing the relative proportions of feedstock and $\mathrm{KOH}^{5-13,34-41}$.

\section{Experimental}

All chemicals were of reagents grade, purchased Merck and orange peel were obtained from cultives Colombian.

\section{Treatment and preparation of sample}

Prior to the use, the orange peel was repeatedly washed with distilled water in order to remove dust and other inorganic impurities, then oven-dried for $24 \mathrm{~h}$ at $393 \mathrm{~K}$ to reduce the moisture content. Peel from Colombian orange were impregnated with aqueous solutions of $\mathrm{KOH}$ following a variant of the incipient wetness method; similar cases have been described in literature ${ }^{9,10,37-42}$. This consists of adding dropwise (while stirring the solid, to facilitate homogeneous absorption of liquid) the amount of aqueous solution $\left(2.0 \mathrm{~mL} \mathrm{~g}^{-1}\right.$ orange peel) necessary to produce swelling until incipient wetness. Different concentrations of $\mathrm{KOH}$ in aqueous solution were used to vary the content of impregnation agent, which will be expressed as impregnation ratio $\left(\mathrm{X}_{\mathrm{p}}, \mathrm{wt} . \%\right)$, defined as (gram $\mathrm{KOH}$ per $\mathrm{g}$ orange peel $) \times 100$. Impregnation ratios of $40,70,110$, and $160 \mathrm{wt}^{\circ} \%$ were used $^{11-14}$. After impregnation, the samples were dried for $8 \mathrm{~h}$ at $383 \mathrm{~K}$ in air. Pyrolysis treatments (activations) were carried out in a vertical tubular reactor made of quartz in furnace Carbolite ${ }^{\mathrm{TM}}$, using in all cases $25 \mathrm{~g}$ of impregnated and dried material. All treatments were done at a constant heating rate of $10 \mathrm{~K} \mathrm{~min}^{-1}$ and with an argon (99.999\% pure) flow of $30 \mathrm{STP} \mathrm{cm}^{3} \mathrm{~min}^{-1}$, which was kept during heating and cooling. An activation temperature of $823 \mathrm{~K}$ and a soaking time of $4 \mathrm{~h}$ were used. After cooling the solid pyrolysis residue to room temperature it was washed with milli-Q distilled water until lowering the conductivity of the washing liquids to $<5 \mu \mathrm{S} \mathrm{cm}^{-1}$ (measured with a pH/conductivity meter HP, model MARK 602). The resulting ACs were dried at $383 \mathrm{~K}$ for $24 \mathrm{~h}$ in a vacuum furnace.

\section{Pore structure characterization}

The porous texture of ACs was characterized by physical adsorption of nitrogen at $77 \mathrm{~K}$ (using an automatic volumetric adsorption apparatus, AUTOSORB 3B from Quantachrome instruments) and carbon dioxide at $273 \mathrm{~K}$ (using a automatic volumetric adsorption apparatus, AUTOSORB 3B from Quantachrome instruments). In either case the samples were degassed overnight at $573 \mathrm{~K}$ before every adsorption measurement. Gases used had minimum purities of $99.999 \%\left(\mathrm{~N}_{2}\right)$ and $99.98 \%\left(\mathrm{CO}_{2}\right) . \mathrm{N}_{2}$ adsorption data were analyzed by means of the BET and Dubinin-Radushkevich (DR) equations, the $\alpha_{\mathrm{S}}$ method (using Spheron- 6 carbon black as reference material) and the density functional theory (DFT). $\mathrm{CO}_{2}$ adsorption data were analyzed by the Dubinin-Radushkevich-Kaganer (DRK) equation. 


\section{Adsorption equilibrium isotherm}

Batch sorption experiments were conducted using $100 \mathrm{~mL}$ aliquots of the test solutions; $\mathrm{pH}$ adjusted containing $100 \mathrm{mg} \cdot \mathrm{L}^{-1}$ of each one of the ions in: $\mathrm{Cr}^{3+}, \mathrm{Cd}^{2+}$ and $\mathrm{Co}^{2+}$ in monocomponent systems; placed in $250 \mathrm{~mL}$ amber closed bottles. A known quantity $(0.01-0.15 \mathrm{~g})$ of $\mathrm{CBC}$ was added to each bottle. Solutions were stirred at $200 \mathrm{rpm}$ for periods between 5 and $110 \mathrm{~min}$ at $298 \pm 1 \mathrm{~K}$. Bone charcoal was removed by filtration and $\mathrm{Cr}^{3+}, \mathrm{Cd}^{2+}$ and $\mathrm{Co}^{2+}$ molar concentrations were measured by atomic absorption spectroscopy (in a Perkin Elmer AAnalyst equipment), at the end of each period of time. Blank solutions were also prepared and analyzed. Solution $\mathrm{pH}$ changes as metal ion concentration changes during adsorption process. A previous survey was made to determine solution $\mathrm{pH}$ which produces maximum adsorption. $\mathrm{pH}$ value of each metal ion solution was adjusted using either $0.01 \mathrm{~N} \mathrm{NaOH}$ or $0.01 \mathrm{~N} \mathrm{HNO}_{3}$ solutions and employed volumes, registered to calculate final solution volume $\mathrm{e}^{21-35}$.

\section{Immersion enthalpy}

Immersion enthalpies of CBC were determined in solutions of $\mathrm{Cr}^{3+}, \mathrm{Cd}^{2+}$, and $\mathrm{Co}^{2+}$ with concentrations ranging from 20 to $100 \mathrm{mg} \cdot \mathrm{L}^{-1}$ for the maximum adsorption $\mathrm{pH}$ of 5.1 . Immersion enthalpies were also determined for $100 \mathrm{mg} \cdot \mathrm{L}^{-1}$ solutions at all $\mathrm{pH}$ values studied. This determination was performed in a isoperibol microcalorimeter with a stainless steel calorimetric cell ${ }^{14,41,42} .30 \mathrm{~mL}$ of the solution to be used were pre-heated at $298 \mathrm{~K}$; then placed in the cell. A sample of approximately $0.500 \mathrm{~g} \mathrm{CBC}$ was weighed and placed inside the calorimetric cell in a glass ampoule. Microcalorimeter was then assembled. When the equipment reached the temperature of $298 \mathrm{~K}$, potential readings were registered after a period of approximately 15 minutes, with readings every 20 seconds, glass ampoule was broken and generated thermal effect registered. Electric potential readings continue for approximately 15 minutes more and at the end of the experience, the equipment was electrically calibrated.

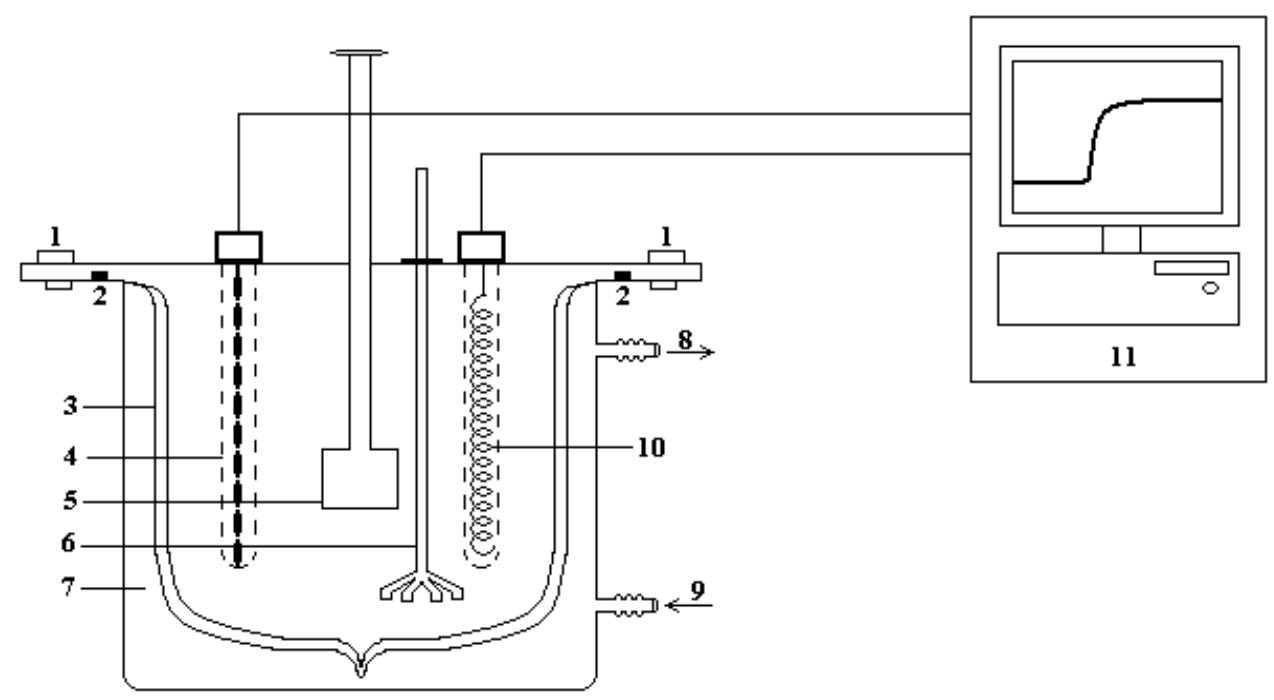

Figure 1. Isoperibol microcalorimeter. 1. Screws. 2. O-ring. 3. Dewar. 4. Thermistors. 5. Glass ampoule. 6. Agitation system. 7. Thermostat. 8 and 9. Water inlet and oulet. 10. Heater resistance. 11. Capture system. 


\section{Results and Discussion}

\section{Physical properties of activated carbons obtained}

The adsorption-desorption isotherms of $\mathrm{N}_{2}$ at $77 \mathrm{~K}$ on ACs from orange peels impregnated with different amounts of $\mathrm{KOH}$. The isotherms (not shown here) are type Ia for the AC with $\mathrm{X}_{\mathrm{p}}=40 \mathrm{wt} . \%$ (typical of microporous materials where micropore filling may take place by primary filling at very low $\left.\mathrm{p} / \mathrm{p}^{0}\right)^{10}$ with a small development of mesopores, and type $\mathrm{Ib}$ when $\mathrm{X}_{\mathrm{p}}=70 \mathrm{wt} . \%$ (typical of microporous materials where micropore filling may take place by co-operative filling in wider micropores over a range of higher $\mathrm{p} / \mathrm{p}^{0}$ than in type Ia) ${ }^{11-14,41,42}$. The AC prepared by impregnation at $\mathrm{X}_{\mathrm{p}}=110 \mathrm{wt} . \%$ gives a type Ib isotherm, but in this case a plateau is not clearly reached, indicating widening of pores; this isotherm exhibits a type $\mathrm{H}_{4}$ hysteresis loop, characteristic of slit-shaped pores. Finally, the AC prepared by impregnation with 160 wt. $\% \mathrm{KOH}$ yields a type Ilb isotherm but with an important adsorption at low $\mathrm{p} / \mathrm{p}^{0}$, indicative of simultaneous presence of micro- and mesopores. Similar evolutions from type I to type II isotherms with increasing amount, but with phosphoric acid have been reported by other authors ${ }^{11-14,39-42}$.

Table 1 reports textural parameters deduced from $\mathrm{N}_{2}$ and $\mathrm{CO}_{2}$ adsorption isotherms. The BET $\left(\mathrm{S}_{\mathrm{BET}}\right)$ and micropore $\left[\mathrm{S}_{\text {microp }}\right.$ ( $\left.\left.\mathrm{DR}, \mathrm{N}_{2}\right)\right]$ surface areas increase with increasing $\mathrm{X}_{\mathrm{p}}$, sharply from $\mathrm{X}_{\mathrm{p}}=100-160 \mathrm{wt} . \%$ and less markedly above the latter impregnation ratio (4070 wt. \%). The micropore surface areas deduced from $\mathrm{CO}_{2}$ isotherms $\left[\mathrm{S}_{\text {microp }}\right.$. $\left.\left(\mathrm{DRK}, \mathrm{CO}_{2}\right)\right]$ go through a maximum at $160 \mathrm{wt} . \%$. The external surface area $\left[\mathrm{S}_{\mathrm{ext}}\left(\alpha_{\mathrm{S}}, \mathrm{N}_{2}\right)\right]$ increases with increasing $\mathrm{X}_{\mathrm{p}}$, slightly at low impregnation ratios and more steeply above $110 \mathrm{wt} . \% \mathrm{KOH}$, as could be expected from the shape of the isotherms.

Table 1. Textural parameters deduced from $\mathrm{N}_{2}$ adsorption at $77 \mathrm{~K}$ and $\mathrm{CO}_{2}$ adsorption at $273 \mathrm{~K}$ on ACs prepared at different impregnation ratios $\left(\mathrm{X}_{\mathrm{P}}\right)$.

\begin{tabular}{|c|c|c|c|c|c|c|c|c|c|c|}
\hline \multirow{3}{*}{$\begin{array}{l}\frac{0}{3} \\
\frac{0}{x} \\
\dot{x}\end{array}$} & \multirow{3}{*}{$\begin{array}{c}\mathrm{N}_{2} \\
\mathrm{~S}_{\mathrm{BE}} \\
\mathrm{T}\end{array}$} & \multirow{3}{*}{ 芉 } & \multirow{3}{*}{$p^{2}$} & \multirow{2}{*}{$\begin{array}{l}\text { DFT- } \\
\text { method }\end{array}$} & \multirow{3}{*}{$\begin{array}{l}\dot{0} \\
\stackrel{0}{0} \\
\stackrel{0}{\Xi} \\
⿱ 亠 䒑 \\
\end{array}$} & \multirow{3}{*}{$\dot{\vec{g}}$} & \multirow{2}{*}{$\begin{array}{c}\text { DR- } \\
\text { method }\end{array}$} & \multirow{3}{*}{ 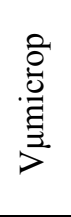 } & \multicolumn{2}{|c|}{$\mathrm{CO}_{2}$} \\
\hline & & & & & & & & & $\begin{array}{c}\text { DRK- } \\
\text { method }\end{array}$ & \\
\hline & & & & V $\mu$ microp & & & Sumicrop & & Sumicrop & $\begin{array}{c}\text { Vumicro } \\
p\end{array}$ \\
\hline \multirow[t]{2}{*}{40} & 676 & 2 & 0.2 & 0.11 & 0.2 & 0.0 & 645 & 0.2 & 564 & 0.19 \\
\hline & & & 7 & & 2 & 2 & & 8 & & \\
\hline \multirow[t]{2}{*}{70} & 763 & 8 & 0.5 & 0.09 & 0.2 & 0.1 & 753 & 0.4 & 564 & 0.27 \\
\hline & & & 1 & & 8 & 8 & & 2 & & \\
\hline 11 & 854 & 9 & 0.8 & 0.07 & 0.2 & 0.3 & 823 & 0.4 & 745 & 0.19 \\
\hline 0 & & & 8 & & 7 & 8 & & 1 & & \\
\hline 16 & 897 & 12 & 1.0 & 0.05 & 0.2 & 0.7 & 856 & 0.5 & 656 & 0.20 \\
\hline 0 & & & 1 & & 2 & 8 & & 7 & & \\
\hline
\end{tabular}

Surface areas in $\mathrm{m}^{2} \mathrm{~g}^{-1}$; pore volumes in $\mathrm{cm}^{3} \mathrm{~g}^{-1}$. The total pore volume, $\mathrm{V}_{\mathrm{p}}\left(\mathrm{N}_{2}\right)$ (calculated from $\mathrm{N}_{2}$ adsorption data as volume of liquid $\mathrm{N}_{2}$ at a relative pressure of 0.975 ) increases continuously with increasing impregnation ratio as does the mesopore volume, $\mathrm{V}_{\mathrm{mp}}$ (DFT, $\mathrm{N}_{2}$ ) (volume of pores with widths between 2 and $50 \mathrm{~nm}$ ). The ultramicropore volume, $\mathrm{V}_{\mu \text { micro. }}\left(\mathrm{DFT}, \mathrm{N}_{2}\right.$ ) (volume corresponding to pores of width $<0.7 \mathrm{~nm}$ ) follows the opposite trend. Let us examine now the variation of the micropore volume as a function of $X_{p}$. Parameters such as $\mathrm{V}_{\mu \text { microp. }}\left(\mathrm{DRK}, \mathrm{CO}_{2}\right)$ ] and $\mathrm{V}_{\mu \text { microp. }}$ (DFT, $\mathrm{N}_{2}$ ) (the latter being calculated as the volume of pores of width $<2 \mathrm{~nm}$ ) go through a maximum at $X_{p}=70 \mathrm{wt} . \%$. The alternative parameter $V_{\mu \text { microp. }}\left(D R, N_{2}\right)$ increases with increasing $X_{p}$ over the entire range of 
impregnation ratios studied, albeit the increase is small above $X_{p}=70$ wt.\%. $V_{\mu \text { microp. }}$ (DRK, $\mathrm{CO}_{2}$ ) is always smaller than $\mathrm{V}_{\text {microp. }}\left(\mathrm{DFT}, \mathrm{N}_{2}\right.$ ) and $\mathrm{V}_{\mu \text { microp. }}\left(\mathrm{DR}, \mathrm{N}_{2}\right.$ ), this being attributable to the presence of wide micropores that are not filled with $\mathrm{CO}_{2}$ at the low relative pressures $(<0.03)$ attained at $273 \mathrm{~K}$; it is well known that, under these conditions, $\mathrm{CO}_{2}$ only measures narrow microporosity ${ }^{11-14}$. The differences between $\mathrm{V}_{\mu \text { microp. }}\left(\mathrm{DFT}, \mathrm{N}_{2}\right.$ ) and $\mathrm{V}_{\mu \text { microp. }}$ (DR, $\mathrm{N}_{2}$ ) are ascribable to the artifactual minimum around $1 \mathrm{~nm}$ that arises systematically in DFT calculations. This minimum, introduced by modelling assumptions ${ }^{12,13}$, certainly contributes to underestimate the micropore volume as calculated by this method.

\section{Effect of activated carbon from orange peel dosage on adsorption}

Figure 2 shows removal of $\mathrm{Cr}^{3+}, \mathrm{Cd}^{2+}$, and $\mathrm{Co}^{2+}$ as a function of ACOP added in aqueous solution of $\mathrm{pH} 5.0$ using of ACOP with area major surface. Activated carbon of orange peel (ACOP) dosage ranged from 0.02 to $0.10 \mathrm{~g}$ for the $100 \mathrm{~mL} \mathrm{of} \mathrm{Cr}^{3+}, \mathrm{Cd}^{2+}$, and $\mathrm{Co}^{2+}$ test solutions and equilibrated for $120 \mathrm{~min}$. It can be seen that the maximum removal expressed as percentage was between $75 \mathrm{mg} / \mathrm{g}$ for ions cobalt to $35 \mathrm{mg} / \mathrm{g}$ for cadmium ion at dosages between $0.02 \mathrm{~g}$ and $0.05 \mathrm{~g}$ of ACOP. Ions removal increases quickly between 5 to $10 \mathrm{ppm}$ as $\mathrm{Ce}$ and reaches a maximum at $500 \mathrm{ppm}$ of Ce of ACOP. This fact may be associated with the $\mathrm{M}^{2+}$ ion availability at $\mathrm{pH}$ 5.0. From $\mathrm{pK}_{\mathrm{h}}$ values, it can be concluded that, at $\mathrm{pH} 5.0, \mathrm{Co}^{2+}$ ions have a concentration 100 times greater than $\mathrm{Cd}^{2+}$ ions, e.g. On the other hand, ionic radius $\mathrm{Cd}^{2+}$ ions have a volume almost $25 \%$ bigger than $\mathrm{Cr}^{3+}$ ions. $\mathrm{Co}^{2+}$ ions are more likely to be in solution rather than adsorbed. The observed constancy in percentage ion removal beyond $100 \mathrm{ppm}$ as Ce may be an indicative of a very weak interaction between adsorbent and adsorbate. This interaction appears weaker with $\mathrm{Cd}^{2+}$ ions than with $\mathrm{Co}^{2+}$ ions. Ion solution concentration seems to attain a steady state with adsorbed species and so, no matter the quantity of adsorbent present, there will be a residual concentration of ions in solution.

This fact determines a specific relation between ion concentration and adsorbent quantity. Adsorption of metal ions on these types of materials is generally attributed to weak interaction between the adsorbents and adsorbates. Surface charges on substrates as well as softness or hardness of the solutes are mostly responsible for the intensity of interaction. Coulombic interaction can be observed for the ionic interexchange of cationic species with anionic sites in the materials and is determined by their surface areas.

\section{Effect of contact time}

Figure 3 shows contact time effect on the ACOP removal maximum of $25 \mathrm{mg} \cdot \mathrm{L}^{-1} \mathrm{Cr}^{3+}$, $\mathrm{Cd}^{2+}$, and $\mathrm{Co}^{2+}$. Removal increases with time and reaches a maximum after 15 min of agitation. Nevertheless, the order of affinity for the adsorbate is maintained: $\mathrm{Cd}^{2+}<$ $\mathrm{Cr}^{3+}<\mathrm{Co}^{2+}$. This is associated with the size of the ion and the pore development in activated carbon from orange peel. 


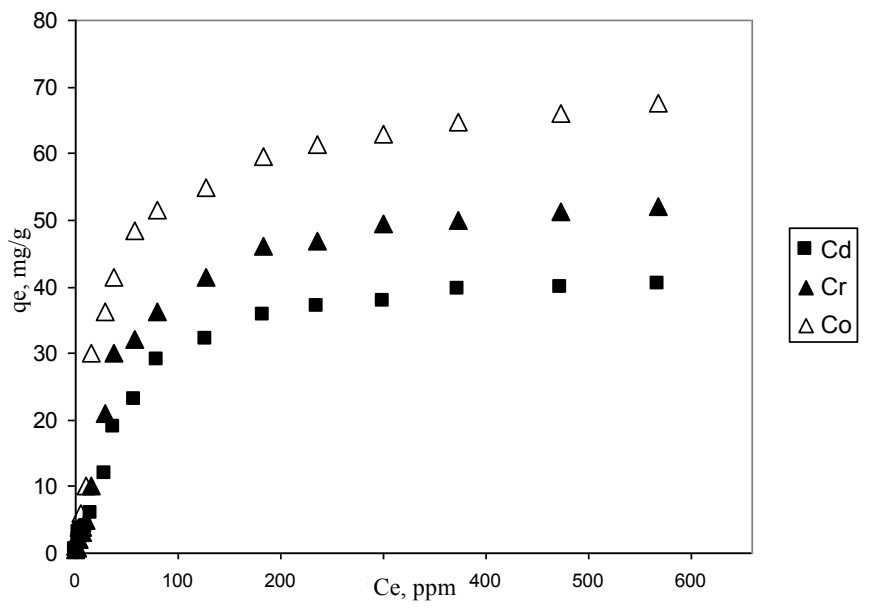

Figure 2. ACOP adsorbent dosage effect on $\mathrm{Cr}^{3+}, \mathrm{Cd}^{2+}$ and $\mathrm{Co}^{2+}$ removal Conditions: $\mathrm{C}_{0}$, $20 \mathrm{mg} \cdot \mathrm{L}^{-1}$; time of contact, $60 \mathrm{~min}$; $\mathrm{pH} 5.0$ and temperature, $298 \mathrm{~K}$.

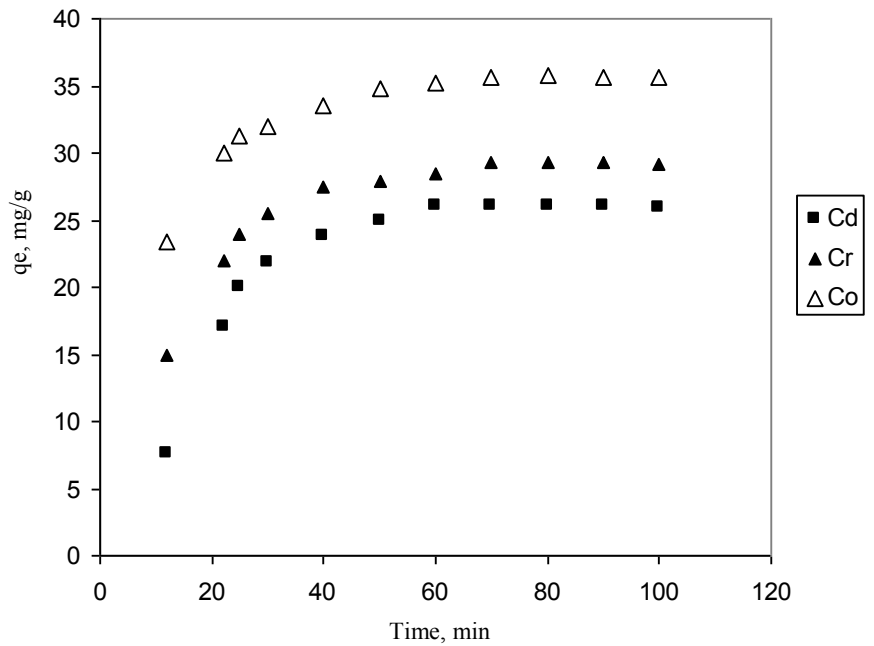

Figure 3. ACOP contact time effect on $\mathrm{Cr}^{3+}, \mathrm{Cd}^{2+}$, and $\mathrm{Co}^{2+}$ removal. Conditions: $\mathrm{C}_{\mathrm{o}}$, $25 \mathrm{mg} \cdot \mathrm{L}^{-1}$; ACOP dose, $0.02 \mathrm{~g}$; $\mathrm{pH} 5.0$ and temperature, $298 \mathrm{~K}$.

To analyze the sorption rates of $\mathrm{Cr}^{3+}, \mathrm{Co}^{2+}$, and $\mathrm{Cd}^{2+}$ ions onto the ACOP, two simple kinetic models were tested.

\section{Pseudo-first-order model}

The pseudo-first order rate expression, popularly known as the Lagergren equation, is generally described by the following equation (Lagergren, 1898 ${ }^{26}$ :

$$
\frac{d q}{d t}=k_{a d}\left(q_{e}-q\right)
$$


Where, $\mathrm{q}_{\mathrm{e}}$ is the amount of the metal ions adsorbed at equilibrium per unit weight of sorbent $(\mathrm{mg} / \mathrm{g})$; $\mathrm{q}$ is the amount of metal ions adsorbed at any time $(\mathrm{mg} / \mathrm{g})$. Besides, $\mathrm{k}_{\mathrm{ad}}$ is the rate constant $\mathrm{min}^{-1}$. Integrating and applying boundary conditions, $\mathrm{t}=0$ and $\mathrm{q}_{\mathrm{t}}=0$ to $\mathrm{t}=\mathrm{t}$ and $\mathrm{q}=$ $\mathrm{q}_{\mathrm{t}}$, Eq. 1 takes the form:

$$
\ln \left(q_{e}-q_{t}\right)=\ln q_{e}-k_{a d} t
$$

However, if the intercept does not equal to the natural logarithm of equilibrium uptake of metal ions, the reaction is not likely to be first-order even if this plot has high correlation coefficient with the experimental data ${ }^{27}$. Correlation coefficients were found to be between 0.9434 and 0.9765 . The correlation coefficients are shown on Table 2 together with the Lagergren rate constants calculated from the slope of Eq. $2^{26}$.

In order to obtain rate constants, the straight-line plots of $\ln \left(\mathrm{q}_{\mathrm{e}}-\mathrm{q}_{\mathrm{t}}\right)$ against $\mathrm{t}$ (time) were made (not shown here). This gave fairly straight lines for all four metal ions on the ACOP. The intercept of this plot should give $\ln \mathrm{q}_{\mathrm{e}}$.

Table 2. Lagergren rate equation constants and pseudo second-order rate equation constants for $\mathrm{Cr}^{3+}, \mathrm{Cd}^{2+}$, and $\mathrm{Co}^{2+}$ adsorption on ACOP.

\begin{tabular}{cccc}
\hline \multicolumn{4}{c}{ Lagergren rate equations constants } \\
\hline Metal ions & $\mathrm{k}_{\mathrm{ad}} \times \mathrm{min}$. & $\mathrm{q} \times$ & \\
& & & \\
$\mathrm{Cd}^{2+}$ & 0.022 & 9.3 & 0.9434 \\
$\mathrm{Cr}^{3+}$ & 0.029 & 10.2 & 0.9687 \\
$\mathrm{Coi}^{2+}$ & 0.032 & 13.3 & 0.9765 \\
& Pseudo second-order rate equation constants & & \\
& $\mathrm{h}_{\mathrm{o}} \times, \mathrm{min} \cdot \mathrm{g} \cdot \mathrm{mg}^{-1}$ & $\mathrm{q}^{\times} \times, \mathrm{g} \cdot \mathrm{mg}^{-1}$ & $\mathrm{R}^{2}$ \\
& & & \\
$\mathrm{Cd}^{2+}$ & 1546.6 & 26.7 & 0.9994 \\
$\mathrm{Cr}^{3+}$ & 1546.5 & 29.7 & 0.9999 \\
$\mathrm{Co}^{2+}$ & 1656.6 & 33.2 & 0.9999 \\
\hline
\end{tabular}

\section{Pseudo-second-order model}

The adsorption data was also analyzed in terms of a pseudo-second order mechanism given by $^{27}$ :

$$
\frac{d q}{d t}=k_{2}\left(q_{e}-q_{t}\right)^{2}
$$

Where, $\mathrm{k}_{2}$ is the rate constant $\left(\mathrm{mg} \cdot \mathrm{g}^{-1} \cdot \mathrm{min}^{-1}\right)$. Integrating the above equation and applying boundary conditions, i.e. $\mathrm{t}=0$ for $\mathrm{q}=0$ and $\mathrm{t}=\mathrm{t}$ for $\mathrm{q}=\mathrm{q}_{\mathrm{t}}$, gives:

$$
\frac{1}{q_{t}}=\frac{1}{h_{o}}+\frac{1}{q_{e}} t
$$


Here, $h_{o}$ is the initial adsorption rate. If the second-order kinetics is applicable, the plot of $t / q$ against $t$ in equation 4 should give a linear relationship from which the constants $\mathrm{q}_{\mathrm{e}}$ and $h_{o}$ can be determined (plot not show here). Linear model gave a good fit to the experimental data. This means that the adsorption can be described by a pseudo-second order rate equation, hence $\mathrm{q}_{e}$ and $\mathrm{h}_{\mathrm{o}}$ were evaluated and presented in Table $2 . \mathrm{R}^{2}$ values are approximate the same for all four metal ions on ACOP with a value of 0.9999. In the limit at initial adsorption time, $\mathrm{h}_{\mathrm{o}}$ is defined $\mathrm{as}^{28}$ :

$$
h_{o}=k_{2} q_{e}^{2}
$$

$\mathrm{k}_{2}$ was calculated for the 3 metal ions and are shown in Table 2. The results obtained are similar to a previous study ${ }^{28}$.

\section{Effect of $p H$}

$\mathrm{Cr}^{3+}, \mathrm{Cd}^{2+}$, and $\mathrm{Co}^{2+}$ uptake as a function of hydrogen ion concentration was determined for $\mathrm{pH}$ values from 2 to 14 . The $\mathrm{pH}$ between 5.0-6.0, hydrogen ions are likely to compete with chromium, cadmium and cobalt ions. At $\mathrm{pH}$ values above $4 \mathrm{Cr}^{3+}, \mathrm{Cd}^{2+}$, and $\mathrm{Co}^{2+}$ might precipitate as hydroxides. $\mathrm{pH}$ effects at equilibrium are presented in Figure 3. Maximum adsorption was observed about $\mathrm{pH}$ 5.0. In general, results indicated that the adsorption is highly $\mathrm{pH}$ dependant. Similar results have been reported in literature ${ }^{19}$.

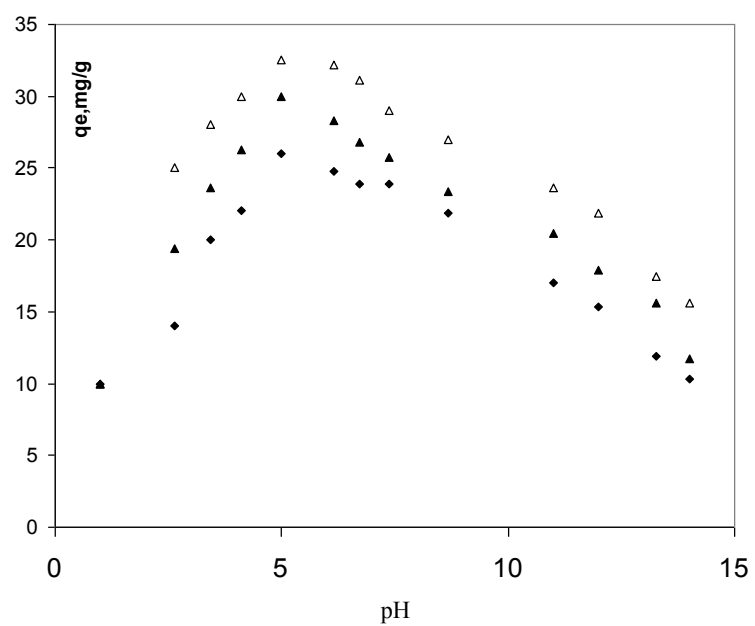

Figure 4. $\mathrm{pH}$ effect on ACOP adsorption of $(\boldsymbol{\Delta}) \mathrm{Cr}^{3+},(\diamond) \mathrm{Cd}^{2+}$, and $(\Delta) \mathrm{Co}^{2+}$. Conditions: $\mathrm{C}_{0}$, $25 \mathrm{mg} / \mathrm{L}$; ACOP dose, $0.02 \mathrm{~g}$; contact time, $20 \mathrm{~min}$ and temperature, $298 \mathrm{~K}$.

$\mathrm{pH}$ values affect species of heavy metals in aqueous solutions and heavy metals removal increases as $\mathrm{pH}$ value rises, reaching a maximum around 5.0. Solution $\mathrm{pH}$ also makes effects on the adsorbent and the surface charge of the ACOP changes. Calculations from solubility products $\left(\mathrm{K}_{\mathrm{sp}}\right)$, predicts the formation of $\mathrm{Co}(\mathrm{OH})_{2}$, occurs at a $\mathrm{pH}$ value of 6 . Precipitation occurs at $\mathrm{pH}$, along with a $\mathrm{q}_{\mathrm{e}}$ of $26.7 \mathrm{mg} \cdot \mathrm{g}^{-1}$. On the other hand, the $\mathrm{q}_{\mathrm{e}}$ has a value of $35 \mathrm{mg} \cdot \mathrm{g}^{-1}$ when the initial $\mathrm{pH}$ was 5.1 (final $\mathrm{pH}$ of 2 ). This means that the removal of cobalt ions from the solution also contributes to the $\mathrm{pH}$ modification. However, at low initial $\mathrm{pH}$ values, below 4 , the influence of adsorption is the only effect responsible for the reducing of 
cobalt ions in the solution. This suggests that the process is a suitable application on heavy metals removal because of its neutral and clean effluent.

\section{Adsorption isotherms from aqueous solution}

When the initial metal concentration rises, adsorption increases while the binding sites are not saturated. Linear Langmuir isotherm allows the calculation of adsorption capacities and the Langmuir constants and is performed by the following equation.

$$
\frac{\mathrm{c}_{e q}}{q}=\frac{1}{q_{\max } b}+\frac{\mathrm{c}_{e q}}{q_{\max }}
$$

Linear plots of $\mathrm{c}_{\mathrm{eq}} / \mathrm{q} v s . \mathrm{c}_{\mathrm{eq}}$ (not shown), were used to calculate by means of linear regression equations, the parameters of the Langmuir isotherm. From these regression equations and the linear plots, the values of the Langmuir constants were calculated and are shown on Table 3. $\mathrm{q}_{\max }$ and $\mathrm{b}$ were obtained from the slope and intercept of the plots. The essential characteristic of the Langmuir isotherms can be expressed in terms of a dimensionless constant separation factor or equilibrium parameter, $\mathrm{R}_{\mathrm{L}}$, which is defined $\mathrm{as}^{32}$ :

$$
\mathrm{R}_{\mathrm{L}}=\frac{1}{\left(1+b \mathrm{c}_{\mathrm{o}}\right)},
$$

Where $b$ is the Langmuir constant and $c_{o}$ is the initial concentration of the metal ions. $R_{L}$ value indicates the shape of the isotherm. $R_{L}$ values between 0 and 1 indicate favorable absorption $^{33}$. $R_{L}$ equal to 0 indicate irreversible absorption, $R_{L}=1$ is linear and $R_{L}>1$ is unfavorable. From our study, $\mathrm{R}_{\mathrm{L}}$ values for $\mathrm{Cr}^{3+}, \mathrm{Cd}^{2+}$ and $\mathrm{Co}^{2+}$ ions adsorption ranged from 0.0050 to 0.0060 . This, for an initial metal ions concentration of $600 \mathrm{mg} \cdot \mathrm{L}^{-1}$. Therefore, adsorption process is favorable. Freundlich isotherm was chosen to estimate the adsorption intensity of the adsorbent towards the adsorbate. It is represented by the equation ${ }^{34}$.

$$
q=K_{\mathrm{F}} \mathrm{c}_{e q}^{\frac{1}{n}}
$$

Where $\mathrm{c}_{\mathrm{eq}}$ is the equilibrium concentration $\left(\mathrm{mg} \cdot \mathrm{L}^{-1}\right), \mathrm{q}$ is the ion amount adsorbed $\left(\mathrm{mg} \cdot \mathrm{g}^{-1}\right)$ and $\mathrm{K}_{\mathrm{F}}$ and $\mathrm{n}$ are constants incorporating all parameters affecting the adsorption process, such as adsorption capacity and intensity respectively. Linear form of Freundlich adsorption isotherm was used to evaluate the sorption data and is represented $\mathrm{as}^{34}$ :

$$
\ln q=\ln K_{\mathrm{F}}+\frac{1}{n} \ln \mathrm{c}_{e q}
$$

Linear regression equation for the Freundlich adsorption isotherm is shown on Table 3. Values of $\mathrm{K}_{\mathrm{F}}$ and $\mathrm{n}$ were calculated from the intercepts and slopes of the Freundlich plots respectively and are shown on this table. Adsorption is favorable for values $0.1<1 / \mathrm{n}<1.0^{35}$. Freundlich equation frequently gives $\mathrm{n}$ adequate description of adsorption data over a restricted range of concentration, even though it is not based on any theoretical background. Apart from a homogeneous surface, Freundlich equation is also suitable for a highly heterogeneous surface and an adsorption isotherm lacking a plateau, indicating a multi-layer adsorption $^{36}$. Values of $1 / \mathrm{n}$, less than unity are an indication that significant adsorption takes place at low concentration but the increase in the amount adsorbed with concentration 
becomes less significant at higher concentration and vice versa ${ }^{37-42}$. The magnitude of $\mathrm{K}_{\mathrm{F}}$ and $\mathrm{n}$, shows that it is possible an easy separation of heavy metal ion from aqueous solution and a high adsorption capacity. Also, as $\mathrm{K}_{\mathrm{F}}$ value increments, the greater the adsorption intensity. Therefore, the $\mathrm{K}_{\mathrm{F}}$ values which are higher for the $\mathrm{Cu}^{2+}$ confirms by these model that the adsorption capacity of is greater than that of the others ions. On the other hand, a relatively high $\mathrm{R}^{2}$ values indicates that this model is adjusted more confidently; this parameter is shown in the Table 4. According to obtained values, Langmuir model fits better the experimental data of the present study.

Table 3. Isotherm parameters of $\mathrm{Cr}^{3+}, \mathrm{Cd}^{2+}$, and $\mathrm{Co}^{2+}$ adsorption on activated carbon from orange peel.

\begin{tabular}{lcccccccc}
\hline & & \multicolumn{3}{c}{ Freundlich model } & \multicolumn{5}{c}{ Langmuir model } \\
\cline { 2 - 9 } & Linear $\mathrm{K}_{\mathrm{D}} \mathrm{L} / \mathrm{g}$ & $\mathrm{K}_{\mathrm{F}}$ & $1 / \mathrm{n}$ & $\mathrm{R}^{2}$ & $\mathrm{q}_{\max }, \mathrm{mg} / \mathrm{g}$ & $\mathrm{B}, \mathrm{L} / \mathrm{g}$ & $\mathrm{R}_{\mathrm{L}}$ & $\mathrm{R}^{2}$ \\
\hline $\mathrm{Cd}^{2+}$ & 8.03 & 24.265 & 0.427 & 0.9745 & 28.67 & 1.09 & 0.006 & 0.9998 \\
$\mathrm{Cr}^{3+}$ & 9.45 & 27.766 & 0.622 & 0.9722 & 30.11 & 1.12 & 0.005 & 0.9988 \\
$\mathrm{Co}^{2+}$ & 12.33 & 44.985 & 0.777 & 0.9887 & 45.44 & 1.55 & 0.005 & 0.9999 \\
\hline
\end{tabular}

\section{Immersion enthalpies}

Results show that immersion enthalpies are constant at low initial concentrations. Initial concentrations above $40 \mathrm{mg} \cdot \mathrm{L}^{-1}$ exhibits a steady increment up to $70 \mathrm{mg} \cdot \mathrm{L}^{-1}$. The highest value of enthalpy was obtained for the immersion of ACOP in the cobalt ions solutions, with the while the lower value of immersion enthalpy was obtained for the immersion of ACOP in the solutions of cadmium ions. Enthalpy values were between $-60 \mathrm{~J} \cdot \mathrm{g}^{-1}\left(\mathrm{Co}^{+}-\mathrm{ACOP}\right)$ and $-25 \mathrm{~J}^{-1}{ }^{-1}\left(\mathrm{Cd}^{2+}-\mathrm{ACOP}\right)$, as shown in Figure 4. This behavior agrees with textural characteristics of activated carbon from orange peel and the sizes of the ions under study. It should be noted that the behavior of immersion enthalpies in the solid prepared in this work, is very similar to that of an isotherm.

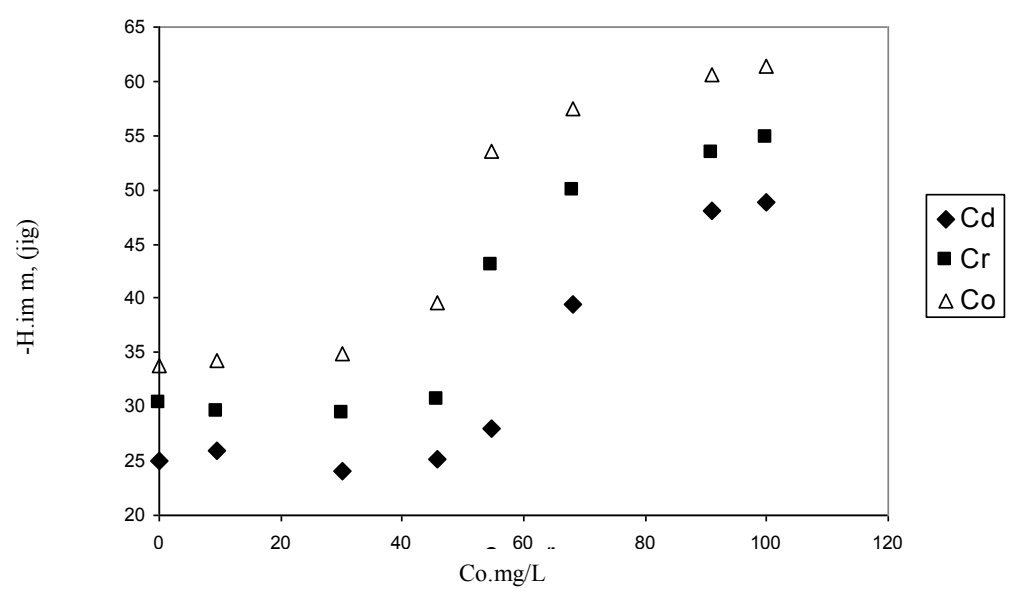

Figure 5. Immersion enthalpies for $\mathrm{Cr}^{3+}, \mathrm{Cd}^{2+}$, and $\mathrm{Co}^{2+}$ aqueous solutions ions concentration at $\mathrm{pH} 5.0, \mathrm{~T}=298 \mathrm{~K}$. 


\section{Removal of $\mathrm{Cr}^{3+}, \mathrm{Cd}^{2+}$ and $\mathrm{Co}^{2+}$ from wastewater}

Just as an approximation for application to a real problem of the results of the present work, we proposed take an industrial wastewater sample. For that purpose we chose waste from a tannery industry for which the content of studied metals was determined. Sample was carefully treated with the aim of perform an analysis of each one of the interest ions and we evaluated the adsorption capacity as the sole comparison parameter. They are analyzed one by one in order to avoid multicomponent systems generation which could produce bias in the obtained results.

Wastewater samples collected in our research laboratory from a textile industry were found to contain more of $500 \mathrm{mg} \cdot \mathrm{L}^{-1}$ of $\mathrm{Cr}^{3+}, \mathrm{Cd}^{2+}$, and $\mathrm{Co}^{2+}$, among other organic and inorganic components. Six samples were treated with nitric acid, followed by $\mathrm{pH}$ adjustment and sorption with ACOP under optimized conditions described before. Metal ions were analyzed one each time by atomic absorption spectrometry, using complexing agent to avoid interference of ions different from that analyzed. Assay for cobalt, chromium and cadmium in the final effluents indicates $60 \%$ maximum removal of the ions originally present in the samples. The minimum removal was $40 \%$ for $\mathrm{Cd}^{2+}$. Mean standard deviation was $2.0 \%$. These results show that ACOP is an adequate material to be used in the removal of these ions. However these findings should be analyzed carefully because of, in spite of employed procedures in order to avoid interferences in the assays, the sample complexity does not let to assure confidence in the results.

\section{Conclusion}

From the experiments, it can be concluded that the ACOP has the ability to retain $\mathrm{Cr}^{3+}, \mathrm{Cd}^{2+}$, and $\mathrm{Co}^{2+}$ metals ions from aqueous solutions at studied concentrations. Removal of heavy metals (cobalt, cadmium and chromium) from aqueous solution was possible using an activated carbon from orange peel (ACOP). It was seen that adsorption took place for the four metals in between 15 and 25 minutes for the concentrations levels studied. Under our experimental conditions, $\mathrm{pH}$ plays an important role in the adsorption process, particularly on the adsorption capacity. Solutions $\mathrm{pH}$ has a great influence on the adsorption capacity for the studied heavy metals. Selected $\mathrm{pH}$ for an optimal rate of adsorption is 5.0 for all ions investigated. It is shown that ACOP has a relatively high adsorption capacity for these heavy metals; the quantities adsorbed per gram of ACOP at equilibrium $\left(\mathrm{q}_{\mathrm{e}}\right)$ are $28.67 \mathrm{mg} \cdot \mathrm{g}^{-1}$ for $\mathrm{Cd}^{2+}, 30.11 \mathrm{mg} \cdot \mathrm{g}^{-1}$ for $\mathrm{Cr}^{3+}$ and $45.44 \mathrm{mg} \cdot \mathrm{g}^{-1}$ for $\mathrm{Co}^{2+}$. This adsorption is described by an isotherm of type I and is fully verified by the Langmuir isotherm. The kinetics of the cobalt, cadmium and chromium adsorption on the ACOP was found to follow a pseudo-secondorder rate equation. This method has an advantage, as it can be applied in developing countries due to the low cost.

\section{Acknowledgement}

Authors wish to thank Master Agreement established between Universidad de los Andes de Colombia and Universidad Nacional de Colombia and the Understanding Memorandum between Departments of Chemistry of both Universities. Special thanks to Fondo Especial de la Facultad de Ciencias and Proyecto Semilla of Universidad de los Andes for the partial financial of this research.

\section{References}

1. $\quad$ Netzer A and Hughes D E, Water Res., 1984,18, 927.

2. Ngah W S W, Endud C S and Mayanar R, React Funct Polym., 2002, 50, 181.

3. Wang K and Xing B, Chemosphere., 2002,48, 665. 
4. Keith K H C, Chemosphere., 2005, 60, 1141.

5. Cheung K C and Venkitachalam T H, Chemosphere., 2000, 41, 243.

6. Rao M, Parwate A V and Bhole A G, Waste Manage., 2002, 22, 821.

7. Yildiz E, Sep Purif Technol., 2004, 35, 241.

8. Gray C A and Schwab A P, Water Air Soil Pollut., 1993, 69, 309.

9. Keith K H and McKay G, J Hazard Mater., 2008, 160, 845.

10. Purevsuren B, Avid B, Narangerel J, Gerelmaa T and Davaajav Y, J Mater Sci., 2004, 9(2), 737.

11. Wilson J A, Pulford I D and Thomas S S, Environ Geochem Health., 2003, 25(1), 51-56.

12. Jiang J Q, Water Sci Technol., 2001, 44(6), 89.

13. Wu F C, Tseng R L and Juang R S, Colloid Interf Sci., 2005, 283, 49.

14. Nasiruddin M, Farooq M and Wahab M, Hazard Mater., 2007, 141 (1), 237.

15. Liu S X, Chen X, Chen X Y, Liu Z F and Wang H L, Hazard Mater., 2007, 141(1), 315.

16. Pattanayak J, Mondal K, Mathew S and Lalvani S B, Carbon, 2000, 38(4), 589.

17. Li Q, Zhai J, Zhang W, Wang M and Zhou J, J Hazard Mater., 2007, 141(1), 163.

18. Garg U K, Kaur M P, Garg V K and Sud D, J Hazard Mater. 2007, 40(1-2), 60.

19. Kavitha D and Namasivayam D., Dyes Pigments, 2007, 4(1), 237.

20. Ofomaja A E and Ho Y S., J Hazard Mater., 2007, 139(2), 356.

21. Chojnacka K, Górecka H and Górecki H, Sci Total Environ., 2006, 366(2-3), 612.

22. Chen S B, Zhu Y G, Ma Y B and McKay G, Environ Pollut., 2006, 39(3), 433.

23. Giraldo L, Cubillos G I and Moreno J C, Rev Colomb Quim., 2005, 34, 147.

24. Findon A, Mckay O and Blair H S, J Environ Sci Heal A, 1993, 28, 173.

25. Weber W J and Digiano F A, Environmental Science and Technology Service, Wiley and Sons, New York, 1996, 89-94.

26. Lagergren S, About the theory of so-called adsorption of soluble substances. Kungliga Svenska Vetenskap-sakademiens. Handlingar, 1998, 24(4), 1.

27. Ho Y S and McKay G, Chem Eng J., 1998, 70(2), 115.

28. Horsfall M and Spiff A I, Electron J Biotech., 2004, 7(3), 1.

29. Pearson R G, Chemical Hardness, Wiley-VCH, Weinheim, Germany, 1997.

30. Chong K H and Volesky H, Biotechnology and Bioengineering, 1995, 47, 451.

31. Langmuir I., J Am Chem Soc., 1918, 40, 1361.

32. Ahalya N, Kanamadi R D and Ramachandra T V, Electronic J Biotechn., 2005, 8, 258.

33. Mckay G, Blair H S and Gardener J R, J Appl Polym Sci., 1982, 27, 3043.

34. Freundlich H, Zeitschrift fr Physikalische Chemie, 1907, 57, 385.

35. Kardivalu K and Namasivayan C, Environ Technol., 2000, 21, 1091.

36. Juang R S, Wu F C and Tseng R L, Water Res., 1999, 33, 2403.

37. Hsisheng C T H, Ind Eng Chem Res., 1998, 39, 3618.

38. Suárez-García F, Martínez-Alonso A and Tascón J M D, Carbon, 2001, 39, 1111.

39. Molina-Sabio M, Rodríguez-Reinoso F, Caturla F and Sellés J M, Carbon, 1995, 33, 1105.

40. Baquero M C, Giraldo L, Moreno J.C, Suárez-García F, Martínez-Alonso A and Tascón J M D, J Therm Anal Appl Pyrol., 2003, 70, 779.

41. Moreno-Piraján Juan Carlos and Giraldo Liliana, J Anal Appl Pyrol., 2010, 87(2), 288.

42. Moreno-Piraján Juan Carlos and Giraldo Liliana, J Anal Appl Pyrol., 2010, 7(2), 188. 


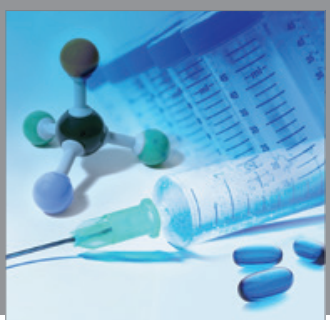

International Journal of

Medicinal Chemistry

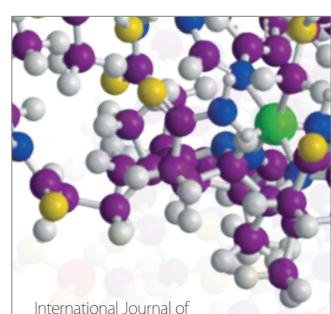

Carbohydrate Chemistry

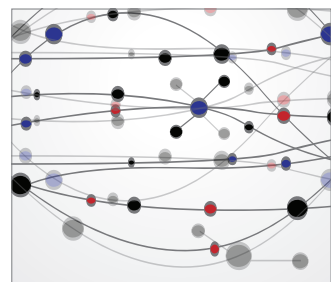

The Scientific World Journal
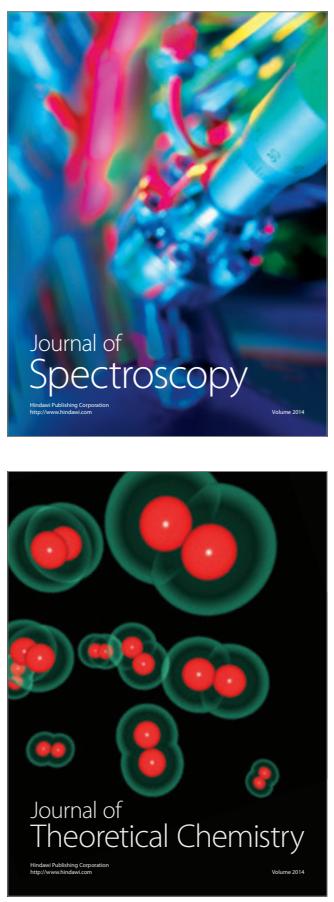
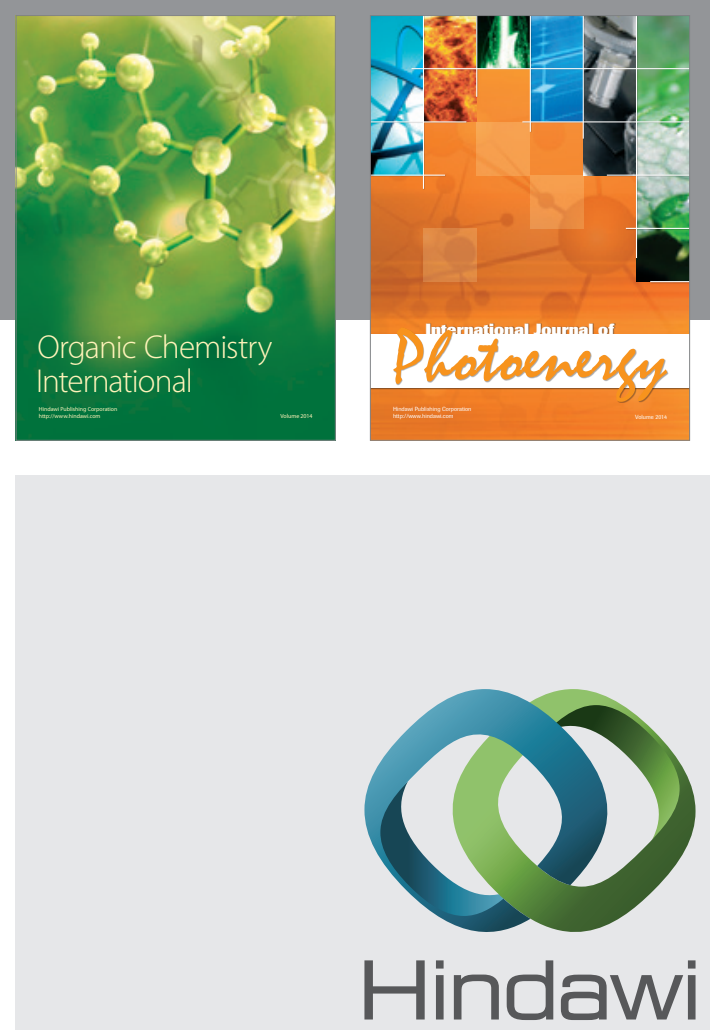

Submit your manuscripts at

http://www.hindawi.com
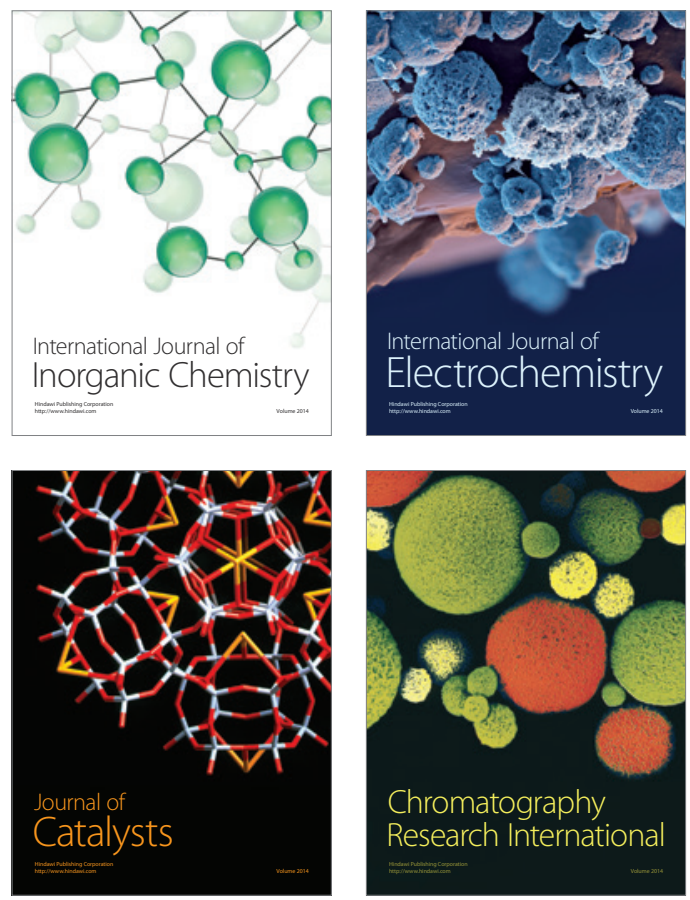
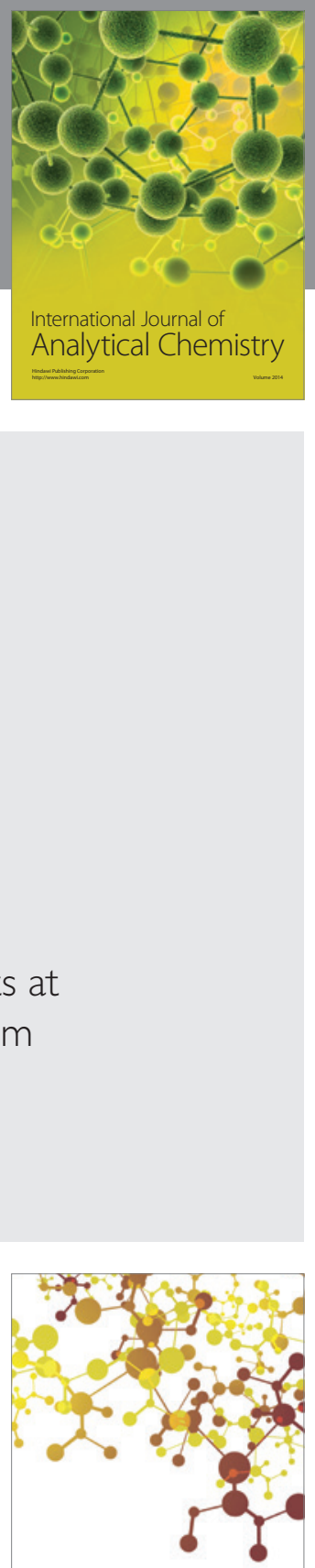

Journal of

Applied Chemistry
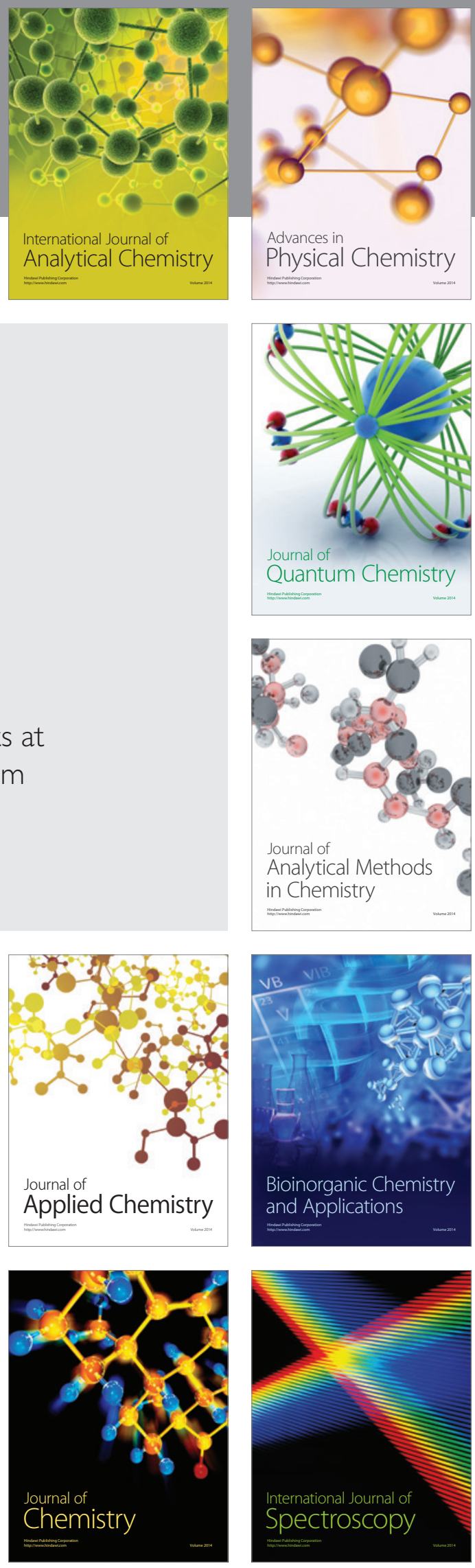